\title{
Performance Comparison between Neutralization Tailings and Flotation Tailings Used for Backfill Mix and Mechanism Analysis
}

\author{
Bin Han, ${ }^{1}$ Wei Sun, ${ }^{2}$ Shaofeng Yu, ${ }^{1}$ Chao Liu, ${ }^{1}$ Song Yao, ${ }^{1}$ and Jianxun $\mathrm{Wu}^{1}$ \\ ${ }^{1}$ School of Civil and Environmental Engineering, University of Science and Technology Beijing, Beijing 100083, China \\ ${ }^{2}$ Faculty of Land Resources Engineering, Kunming University of Science and Technology, Kunming 650093, China \\ Correspondence should be addressed to Wei Sun; kmustsw@qq.com
}

Received 25 February 2016; Revised 23 May 2016; Accepted 29 May 2016

Academic Editor: Ying Li

Copyright (C) 2016 Bin Han et al. This is an open access article distributed under the Creative Commons Attribution License, which permits unrestricted use, distribution, and reproduction in any medium, provided the original work is properly cited.

A comparison test of different tailings used for underground backfill was conducted, using neutralized tailings from BIOX and flotation tailings of Jinfeng Mine. Laboratory comparison test results show that, with neutralized tailings, when the cement dosage is at 19\%, backfill UCS after 7 days, 14 days, and 28 days are 105\%-163\%, 80\%-102\%, and 33\%-43\%, respectively, which are higher than those of flotation tailings. When the cement dosage is at $12 \%$, backfill UCS after 7 days, 14 days, and 28 days are $58 \%-77 \%$, $50 \%-60 \%$, and $28 \%-51 \%$, respectively, which are higher than those of flotation tailings. Slurry fluidity of neutralized tailings is lower than that of flotation tailings, while, in these two tailings, the difference of slump and diffusivity values is less than $6 \%$, which is not a significant difference in slurry fluidity. The reason for neutralized tailings showing higher UCS is as follows: during backfill curing, neutralization tailings produce abundant crystals of $\mathrm{CaSO}_{4} \cdot 2 \mathrm{H}_{2} \mathrm{O}$ in interlaced structure which helps in combining aggregates closely; $\mathrm{CaSO}_{4} \cdot 2 \mathrm{H}_{2} \mathrm{O}$ hydrates with $\mathrm{C}_{3} \mathrm{~A} \mathrm{C} \mathrm{C}_{4} \mathrm{AF}$ contained in the cement and forms clavate cement bacillus which works as a micro reinforcing steel bar. The test proved that neutralized tailings are more optimal for backfilling.

\section{Introduction}

Backfilling the underground mining voids with tailings not only reduces or eliminates the waste pile, but also relieves the pressure on tailing storage, eliminating the risk of dam failure, and also prevents surface subsidence caused by underground mining. Backfill using tailings has become an inevitable choice for underground backfill [1-4]. Biooxidation (BIOX) leaching process is the fastest growing processing and most promising application of smelting technology. It not only increases the rate of metal leaching substantially, but also is an environmentally friendly process. China's biooxidation technology has entered the engineering application stage. Jinfeng Mine has built the world's second largest bacterial oxidation process. The neutralization tailings are a product from the BIOX process in the Jinfeng processing plant. Compared with flotation tailings, the neutralization tailings contain high chemical composition of $\mathrm{FeAsO}_{4}, \mathrm{CaSO}_{4}$, and $\mathrm{Fe}(\mathrm{OH})_{3}$ (about $5 \%$ of the total tailing weight) and have finer grain sizes. In the present work, the backfill mix laboratory comparison test is carried out by using flotation tailings and neutralization tailings from Jinfeng Gold Mine. The result shows that UCS can increase by $58 \%-163 \%, 60 \%-80 \%$, and $51 \%-84 \%$ over a period of 7 days, 14 days, and 28 days of backfill, respectively, in the case of neutralization tailings compared with that of flotation tailings. The backfill slurry fluidity for both kinds of tailings is almost the same; the difference in slump and diffusivity values is less than $6 \%$. The present study is significant in reducing the cost of backfill in Jinfeng Gold Mine and can be a valuable reference for optimization of backfill mixing ratio to other mines with similar biological leaching processing.

\section{Laboratory Backfill Mix Design and Optimization}

2.1. Experimental Purpose. Constrained by high stowing gradient (ratio of whole backfill pipe length to vertical height of the pipe), the maximal slurry filling density in Jinfeng 
TABLE 1: Backfill mix design scheme for $75 \%$ density.

\begin{tabular}{|c|c|c|c|c|c|c|c|}
\hline Number & $\begin{array}{c}\text { Cement } \\
\text { content } / \%\end{array}$ & $\begin{array}{l}\text { Aggregates/tailings } \\
\text { ratio }\end{array}$ & $\begin{array}{l}\text { Tailings } \\
\text { type }\end{array}$ & Number & $\begin{array}{c}\text { Cement } \\
\text { content } / \%\end{array}$ & $\begin{array}{l}\text { Aggregates/tailings } \\
\text { ratio }\end{array}$ & Tailings type \\
\hline $\mathrm{A} 1$ & 19 & 1.4 & \multirow{10}{*}{$\begin{array}{l}\text { Flotation } \\
\text { tailings }\end{array}$} & A11 & 19 & 1.4 & \multirow{10}{*}{$\begin{array}{c}\text { Neutralization } \\
\text { tailings }\end{array}$} \\
\hline $\mathrm{A} 2$ & 19 & 2.4 & & $\mathrm{~A} 12$ & 19 & 2.4 & \\
\hline A3 & 19 & 3.4 & & $\mathrm{~A} 13$ & 19 & 3.4 & \\
\hline A4 & 19 & 4.4 & & A14 & 19 & 4.4 & \\
\hline A5 & 19 & 5.4 & & A15 & 19 & 5.4 & \\
\hline A6 & 12 & 1.4 & & A16 & 12 & 1.4 & \\
\hline A7 & 12 & 2.4 & & A17 & 12 & 2.4 & \\
\hline A8 & 12 & 3.4 & & A18 & 12 & 3.4 & \\
\hline A9 & 12 & 4.4 & & A19 & 12 & 4.4 & \\
\hline $\mathrm{A} 10$ & 12 & 5.4 & & $\mathrm{~A} 20$ & 12 & 5.4 & \\
\hline
\end{tabular}

TABLE 2: The results of the first experiment.

\begin{tabular}{|c|c|c|c|c|c|c|c|c|c|c|c|}
\hline \multirow{2}{*}{ Number } & \multirow{2}{*}{ Slump (mm) } & \multirow{2}{*}{ Diffusivity (mm) } & \multicolumn{3}{|c|}{ UCS (MPa) } & \multirow{2}{*}{ Number } & \multirow{2}{*}{ Slump (mm) } & \multirow{2}{*}{ Diffusivity (mm) } & \multicolumn{3}{|c|}{ UCS (MPa) } \\
\hline & & & $7 \mathrm{~d}$ & $14 \mathrm{~d}$ & $28 \mathrm{~d}$ & & & & $7 \mathrm{~d}$ & $14 \mathrm{~d}$ & $28 \mathrm{~d}$ \\
\hline A1 & 175 & 320 & 1.43 & 3.07 & 3.63 & A11 & 140 & 220 & 3.1 & 4.67 & 5.54 \\
\hline A2 & 250 & 530 & 1.17 & 2.56 & 3.55 & $\mathrm{~A} 12$ & 265 & 620 & 3.7 & 6.01 & 7.19 \\
\hline A3 & 265 & 770 & 1.13 & 2.81 & 3.71 & A13 & 280 & 870 & 2.6 & 4.37 & 6.50 \\
\hline A4 & 275 & 1090 & 1.37 & 2.88 & 3.93 & A14 & 285 & 1025 & 1.9 & 2.70 & 3.79 \\
\hline A5 & 280 & 1140 & 1.57 & 2.87 & 4.22 & A15 & 285 & 845 & 2.1 & 2.60 & 4.19 \\
\hline A6 & 160 & 280 & 0.77 & 1.24 & 1.74 & A16 & 140 & 268 & 1.33 & 2.24 & 3.53 \\
\hline A7 & 265 & 735 & 0.67 & 1.12 & 1.36 & A17 & 255 & 503 & 1.20 & 2.41 & 2.70 \\
\hline A8 & 270 & 825 & 0.57 & 1.00 & 1.51 & A18 & 283 & 850 & 1.07 & 1.49 & 2.07 \\
\hline A9 & 273 & 865 & 0.56 & 1.11 & 1.47 & A19 & 278 & 885 & 0.84 & 1.23 & 1.77 \\
\hline $\mathrm{A} 10$ & 260 & 960 & 0.68 & 1.18 & 1.66 & A 20 & 288 & 1035 & 0.71 & 1.09 & 1.60 \\
\hline
\end{tabular}

Gold Mine is not more than $76 \%$, with $19 \%$ cement dosage for underhand mining and $12 \%$ cement dosage for overhand drift mining. The aggregate/tailings ratio by weight is $1.4-5.4$ and the backfill mix design scheme based on actual Jinfeng mining condition is determined and shown in Table 1 [5-10].

2.2. Experimental. Backfill slurry is prepared according to Table 1. The slump and diffusivity values are tested after mixing by using JS-15 mixer. The slurry is poured into $\varphi$ $80 \mathrm{~mm} \times 200 \mathrm{~mm}$ cylindrical molds and cured for 24 hours in the laboratory and then the specimens were kept in the curing tank in which the temperature is $30^{\circ} \mathrm{C}$ and humidity is $95 \%$. The block is cut into $\varphi 80 \mathrm{~mm} \times 160 \mathrm{~mm}$ size after it is cured for the scheduled curing period. And 7-day, 14-day, and 28day uniaxial compressive strengths are found using a WES100 hydraulic universal testing machine. In order to ensure the accuracy of the experimental results, the experiments in Table 1 were carried out twice separately.

\section{Analysis of Experimental Results}

3.1. Experimental Results. Experimental results are shown in Tables 2 and 3.

\subsection{Analysis of the Impact on Backfill Strength from Different Tailings}

3.2.1. Comparative Analysis of Backfill Strength. Figures 1-6 show backfill strength at the cement content of $19 \%$ and $12 \%$ over different curing periods. In the figures, $\mathrm{Z}$ refers to test results of backfill strength using neutralization tailings and $\mathrm{F}$ refers to test results using flotation tailings. ZR and FR refer to test results of repeat tests with neutralization and flotation tailings, respectively. 7 days, 14 days, and 28 days refer to curing period of backfill.

3.2.2. Analysis of the Impact on Backfill Strength from Different Tailings. The effect of two types of tailings on backfill strength is shown in Tables 4 and 5.

The results shown in Table 4 indicate the following:

(1) Two rounds of backfill comparison experiments with neutralization tailings and flotation tailings show that, at cement content of 19\%, 7-day, 14-day, and 28day strengths of neutralization tailings are higher than those of flotation tailings by $105 \%-163 \%, 80 \%-$ $102 \%$, and $33 \%-43 \%$, respectively, and, at cement dosage of 12\%, 7-day, 14-day, and 28-day strengths of 
TABLE 3: The results of the second experiment.

\begin{tabular}{|c|c|c|c|c|c|c|c|c|c|c|c|}
\hline \multirow{2}{*}{ Number } & \multirow{2}{*}{ Slump (mm) } & \multirow{2}{*}{ Diffusivity (mm) } & \multicolumn{3}{|c|}{ UCS (MPa) } & \multirow{2}{*}{ Number } & \multirow{2}{*}{ Slump (mm) } & \multirow{2}{*}{ Diffusivity (mm) } & \multicolumn{3}{|c|}{ UCS (MPa) } \\
\hline & & & $7 \mathrm{~d}$ & $14 \mathrm{~d}$ & $28 \mathrm{~d}$ & & & & $7 \mathrm{~d}$ & $14 \mathrm{~d}$ & $28 \mathrm{~d}$ \\
\hline A1 & 200 & 320 & 1.48 & 2.15 & 3.52 & A11 & 240 & 460 & 1.77 & 3.20 & 4.73 \\
\hline A2 & 250 & 530 & 1.22 & 1.97 & 3.63 & $\mathrm{~A} 12$ & 250 & 640 & 1.83 & 2.47 & 4.71 \\
\hline A3 & 280 & 900 & 1.07 & 1.76 & 3.37 & $\mathrm{~A} 13$ & 260 & 780 & 2.44 & 4.33 & 4.98 \\
\hline $\mathrm{A} 4$ & 270 & 880 & 1.11 & 1.93 & 3.54 & $\mathrm{~A} 14$ & 260 & 740 & 2.43 & 3.13 & 5.00 \\
\hline A5 & 280 & 880 & 1.19 & 2.13 & 3.61 & $\mathrm{~A} 15$ & 270 & 910 & 1.51 & 2.63 & 4.06 \\
\hline A6 & 135 & 400 & 0.54 & 0.91 & 1.58 & A16 & 170 & 250 & 1.13 & 2.00 & 2.33 \\
\hline A7 & 160 & 690 & 0.44 & 0.78 & 1.52 & $\mathrm{~A} 17$ & 250 & 610 & 0.82 & 1.07 & 1.63 \\
\hline A8 & 265 & 750 & 0.46 & 0.70 & 1.41 & A18 & 260 & 790 & 0.74 & 0.97 & 1.63 \\
\hline A9 & 270 & 780 & 0.43 & 0.73 & 1.31 & A19 & 260 & 690 & 0.73 & 1.17 & 1.98 \\
\hline A10 & 260 & 780 & 0.43 & 0.80 & 1.41 & A20 & 260 & 860 & 0.66 & 1.06 & 1.66 \\
\hline
\end{tabular}

TABLE 4: UCS backfill strength comparison of two types of tailings.

\begin{tabular}{lccccc}
\hline & \multicolumn{2}{c}{ UCS using $19 \%$ cement replacement (MPa) } & \multicolumn{2}{c}{ UCS using 12\% cement replacement (MPa) } \\
& $7 \mathrm{~d}$ & $14 \mathrm{~d}$ & $28 \mathrm{~d}$ & $28 \mathrm{~d}$ & $14 \mathrm{~d}$ \\
\hline $\begin{array}{l}\text { First experiment using flotation } \\
\text { tailings }\end{array}$ & 1.02 & 2.26 & 3.81 & 0.65 & 1.13 \\
$\begin{array}{l}\text { First experiment using } \\
\text { neutralization tailings }\end{array}$ & 2.68 & 4.07 & 5.44 & 1.03 & 1.69 \\
$\begin{array}{l}\text { Second experiment using flotation } \\
\text { tailings }\end{array}$ & 0.98 & 1.56 & 3.53 & 0.46 & 0.78 \\
$\begin{array}{l}\text { Second experiment using } \\
\text { neutralization tailings }\end{array}$ & 2.00 & 3.15 & 4.70 & 0.82 & 1.45 \\
\hline
\end{tabular}

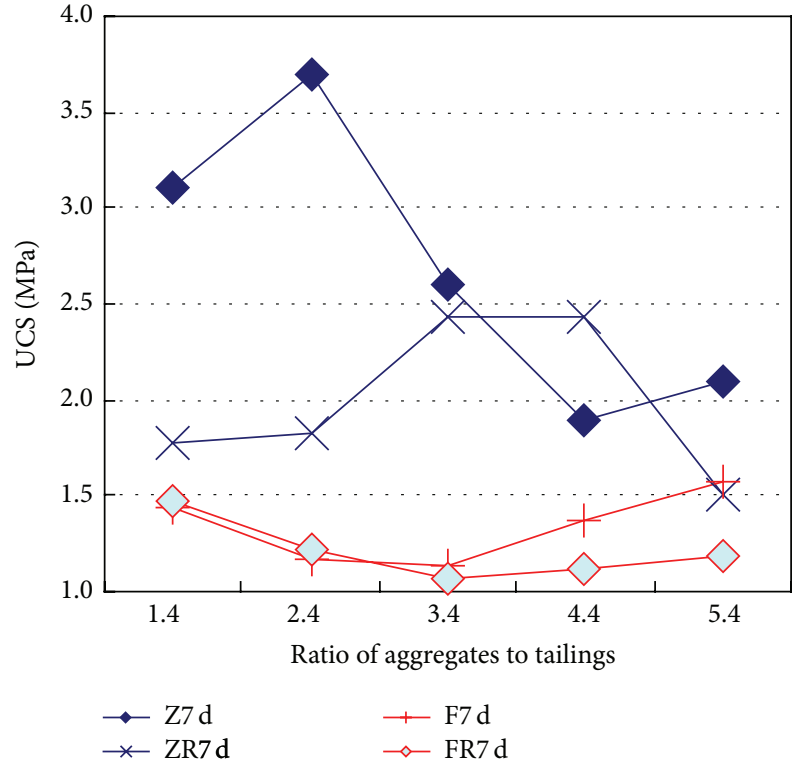

FIGURE 1: 7-day backfill UCS using 19\% cement replacement.

neutralization tailings are higher by $58 \%-77 \%, 50 \%-$ $60 \%$, and $28 \%-51 \%$.

(2) Neutralization tailing is helpful in gaining the early stage backfill strength, which is very important in

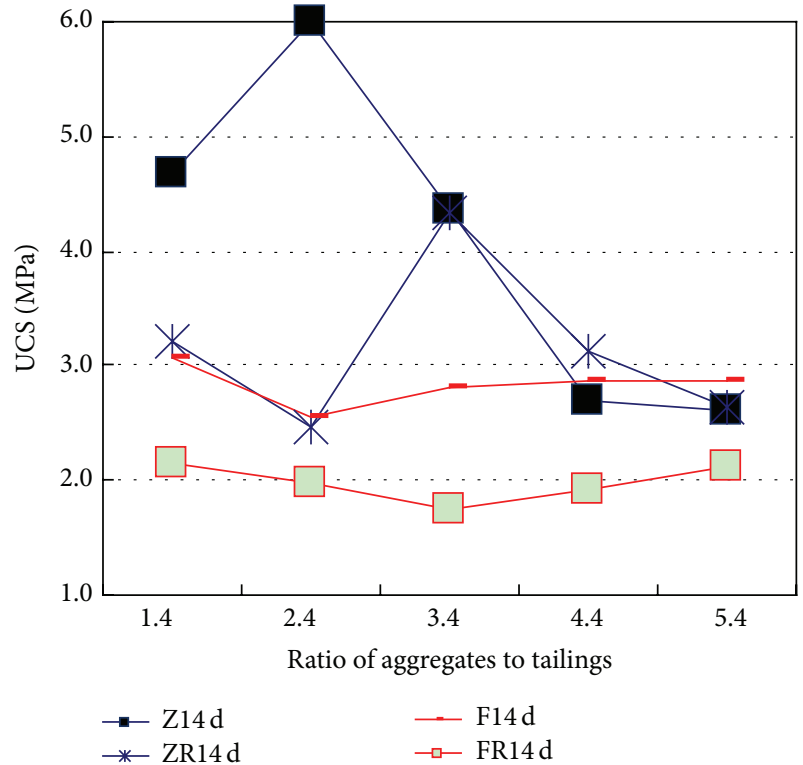

Figure 2: 14-day backfill UCS using 19\% cement replacement.

reducing the curing time of backfill in drives and improving the production from stope.

(3) When neutralization tailing is used for backfilling, the UCS value is nearly in inverse relation with aggregates-to-tailings ratio. The strength of backfill 
TABLE 5: Comparison of backfill slurry flow behavior.

\begin{tabular}{|c|c|c|c|c|}
\hline \multirow{2}{*}{ Items } & \multicolumn{2}{|c|}{ Average flow at $19 \%$ cement replacement } & \multicolumn{2}{|c|}{ Average flow at $12 \%$ cement replacement } \\
\hline & Slump (mm) & Diffusivity (mm) & Slump (mm) & Diffusivity (mm) \\
\hline 1st-round test with flotation tailings & 249 & 770 & 246 & 733 \\
\hline 1st-round test with neutralization tailings & 251 & 716 & 249 & 708 \\
\hline 2nd-round test with flotation tailings & 256 & 702 & 218 & 680 \\
\hline 2nd-round test with neutralization tailings & 256 & 706 & 240 & 640 \\
\hline
\end{tabular}

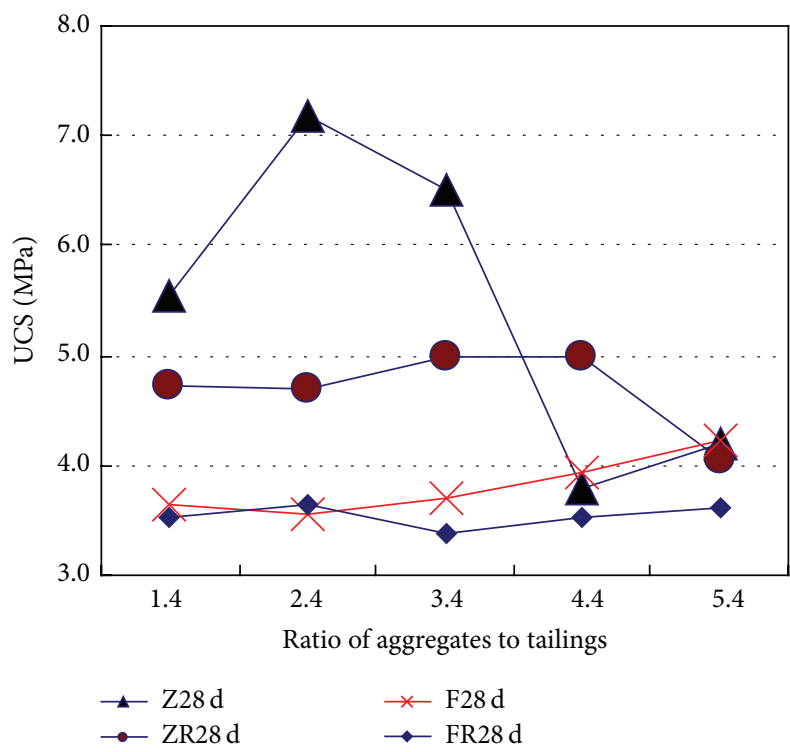

FIGURE 3: 28-day backfill UCS using 19\% cement replacement.

reaches its maximum when the ratio of aggregates to tailings is 2.4; thus, using neutralization tailings for backfill can further increase the portion of tailings while reducing the consumption of crushed waste, with the benefits of not only reducing backfill cost but also developing green mine.

\subsection{Impact on Backfill Slurry Application Liquidity from Different Tailings}

3.3.1. Comparative Analysis of Backfill Slurry Slump and Diffusivity. The test results of backfill slurry slump and diffusivity using two kinds of tailings are shown in Figures 7-10.

3.3.2. Impact on Backfill Slurry Liquidity from Different Tailings. Table 5 gives the comparison on backfill slurry flow behavior with two kinds of tailings.

The result in Table 5 indicates the following:

(1) Neutralization tailings contain more of the fine particles when the percentages of cement replacement of both kinds of tailings are the same. The flow behavior of backfill with neutralization tailings is less active than that of flotation tailings. As the value of slump

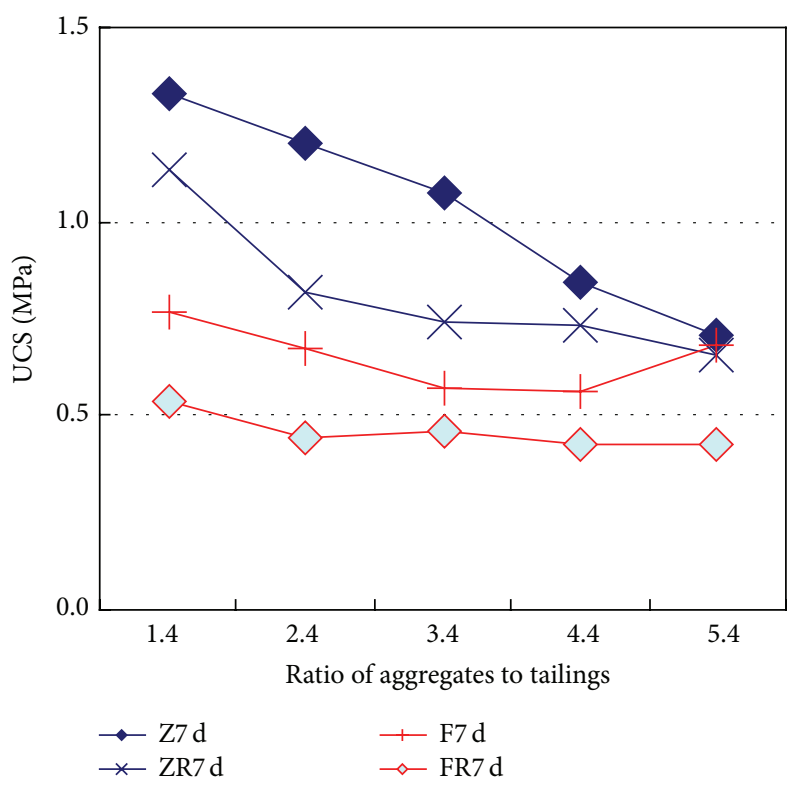

FIGURE 4: 7-day backfill UCS using 12\% cement replacement.

and diffusivity for two kinds of tailings is not more than $6 \%$, it does not have any impact on liquidity.

(2) Because different tailings do not show significant impact on liquidity, the usage of neutralization tailings instead of flotation tailings does not need any modification to current piping system to backfill in Jinfeng, nor does it need to reduce the density of backfill slurry.

\section{Mechanism Analysis of Impact on Backfill Strength from Neutralization Tailings}

4.1. Reaction Mechanism of Neutralization Process. The slurry from BIOX goes through CCD (countercurrent decantering) and the overflow of CCD is added with flotation tailings and limed, going through a thickener, and the tailings from the underflow of the thickener are neutralization tailings. The overflow from CCD thickener contains high volume of sulfuric acid, ferrite, and arsenic. Due to environment concern, this overflow needs to be neutralized. To form a stable, safe, and environmentally friendly arsenic acid iron compound, wastewater must go through 2 stages of neutralization. The first stage neutralizes the $\mathrm{pH}$ value of flotation tailings to 5 , 


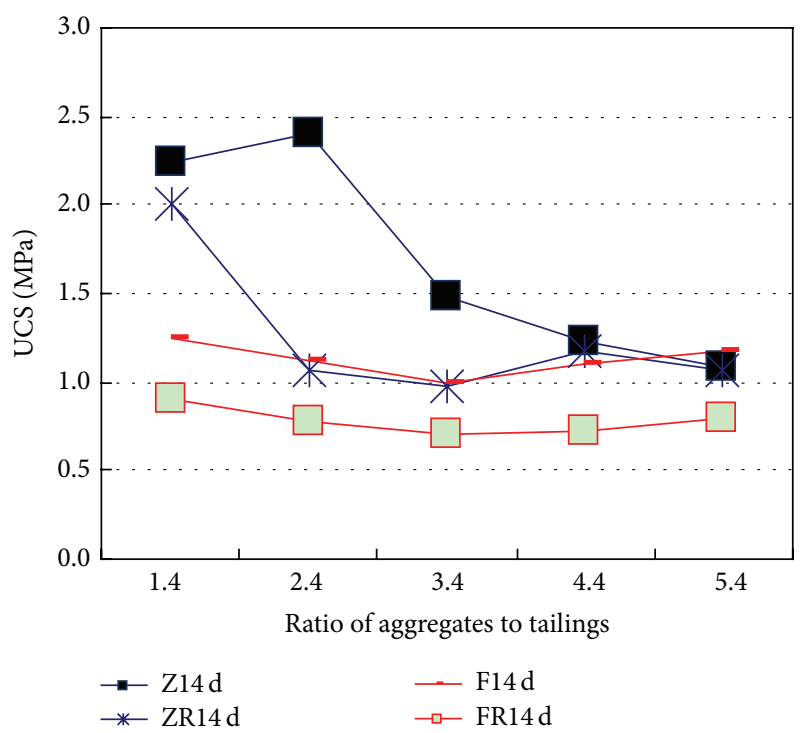

FIGURE 5: 14-day backfill UCS using 12\% cement replacement.

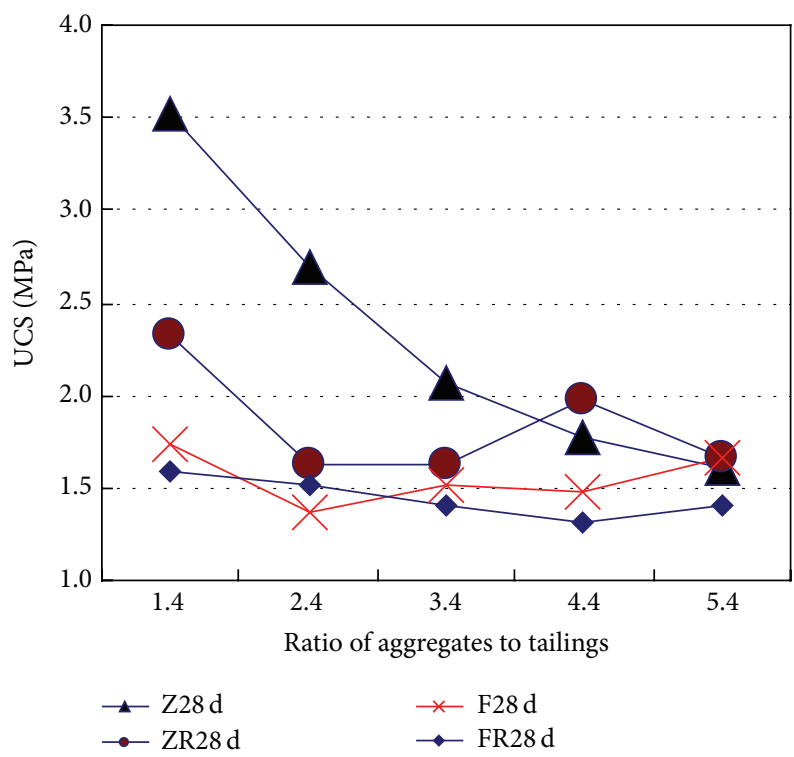

FIGURE 6: 28-day backfill UCS using 12\% cement replacement.

and, in the second stage, lime is added and the $\mathrm{pH}$ value reaches 7 . The neutralization reaction process is as follows. to 5 :

The first stage neutralizes the $\mathrm{pH}$ value of flotation tailings

$$
\begin{aligned}
& 2 \mathrm{H}_{3} \mathrm{AsO}_{4}+\mathrm{Fe}_{2}\left(\mathrm{SO}_{4}\right)_{3}+3 \mathrm{CaCO}_{3} \\
& \longrightarrow 2 \mathrm{FeAsO}_{4}+3 \mathrm{CaSO}_{4}+\mathrm{CO}_{2}+\mathrm{H}_{2} \mathrm{O} \\
& \mathrm{Fe}_{2}\left(\mathrm{SO}_{4}\right)_{3}+3 \mathrm{CaCO}_{3}+3 \mathrm{H}_{2} \mathrm{O} \\
& \quad \longrightarrow 2 \mathrm{Fe}(\mathrm{OH})_{3}+3 \mathrm{CaSO}_{4}+3 \mathrm{CO}_{2}
\end{aligned}
$$

In the second stage, lime is added and the $\mathrm{pH}$ value reaches 7:

$$
\mathrm{H}_{2} \mathrm{SO}_{4}+\mathrm{CaO} \longrightarrow \mathrm{CaSO}_{4}+\mathrm{H}_{2} \mathrm{O}
$$

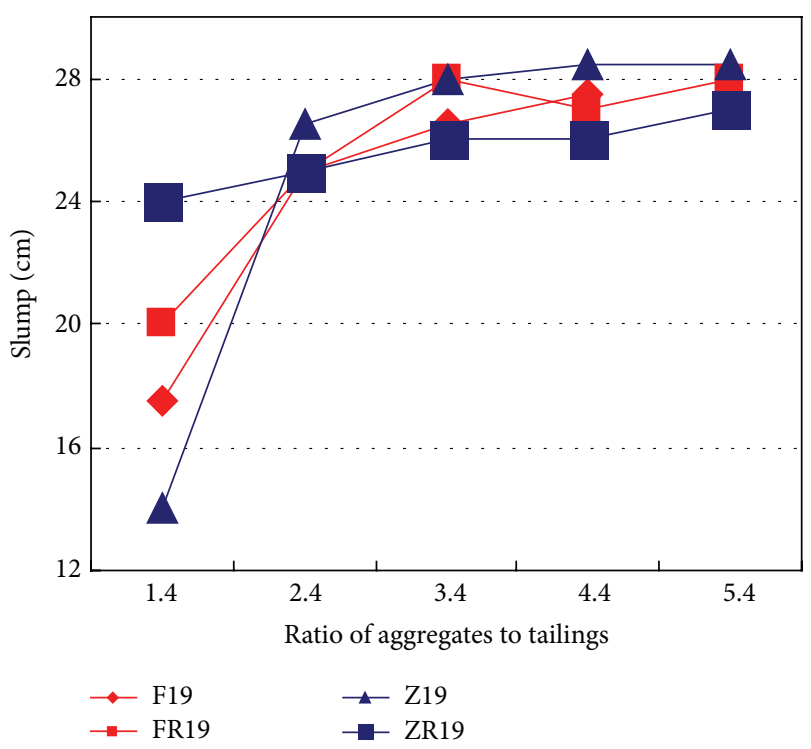

FIGURE 7: Backfill slurry slump using 19\% cement content.

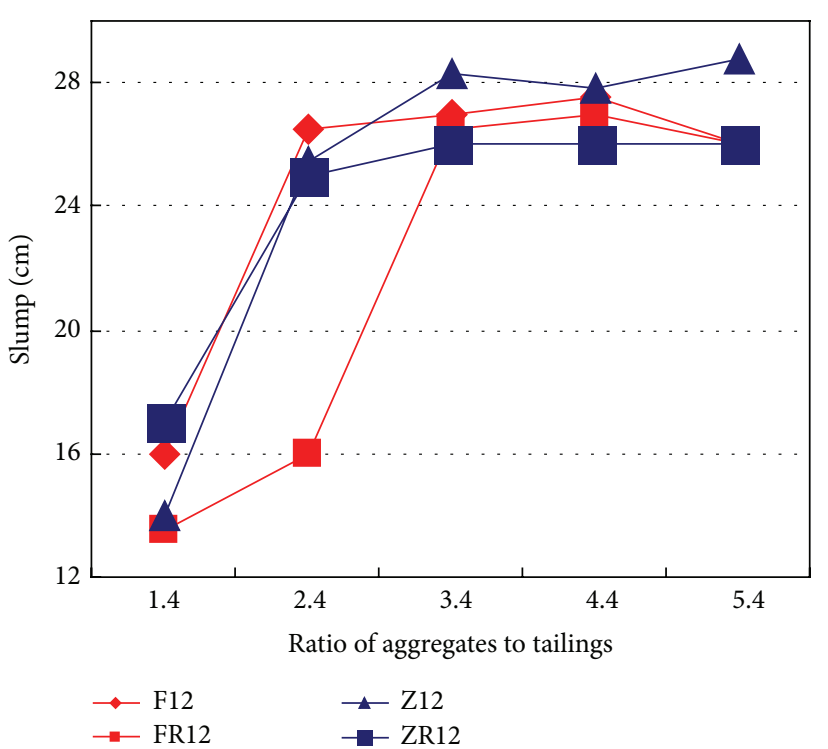

FIGURE 8: Backfill slurry slump using 12\% cement content.

The tailings formed by lime neutralization are called neutralization tailings, for which $\mathrm{pH}$ is 7 .

Figure 11 shows the X-ray diffraction, which indicates high gypsum content in neutralization tailings.

4.2. Cement Hydration Reaction Mechanism. Backfill in Jinfeng uses 32.5 grand portland cement in which the main chemical content is silicate mineral (dicalcium silicate and tricalcium silicate), calcium aluminate mineral, and ferroaluminate mineral. The hydration reaction processes are as follows:

$$
\begin{aligned}
& 2\left(3 \mathrm{CaO} \cdot \mathrm{SiO}_{2}\right)+6 \mathrm{H}_{2} \mathrm{O} \\
& \longrightarrow 3 \mathrm{CaO} \cdot 2 \mathrm{SiO}_{2} \cdot 3 \mathrm{H}_{2} \mathrm{O}+3 \mathrm{Ca}(\mathrm{OH})_{2}
\end{aligned}
$$




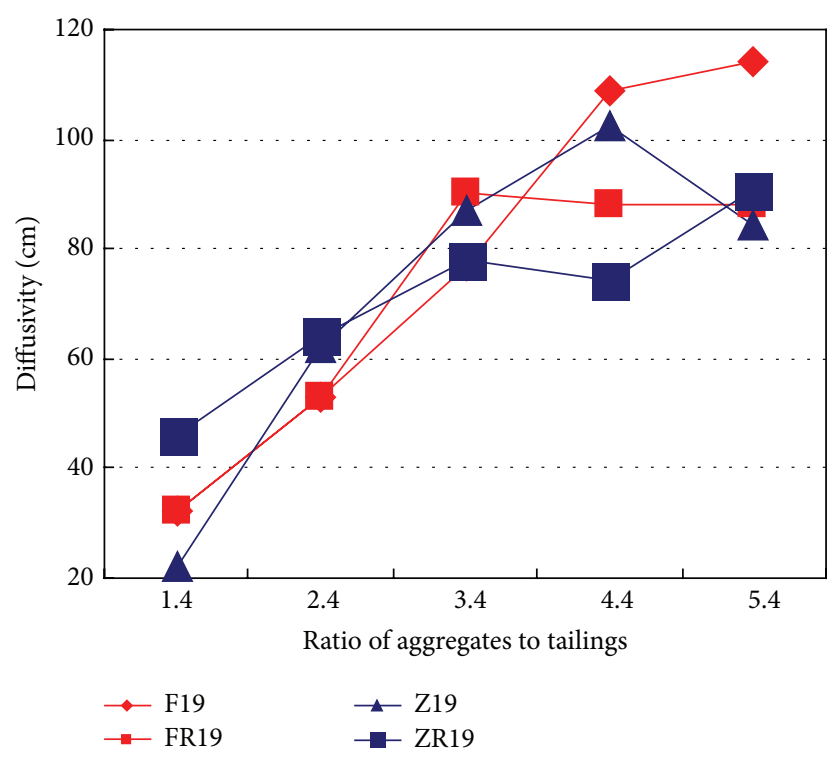

FIGURE 9: Backfill slurry diffusivity using 19\% cement content.

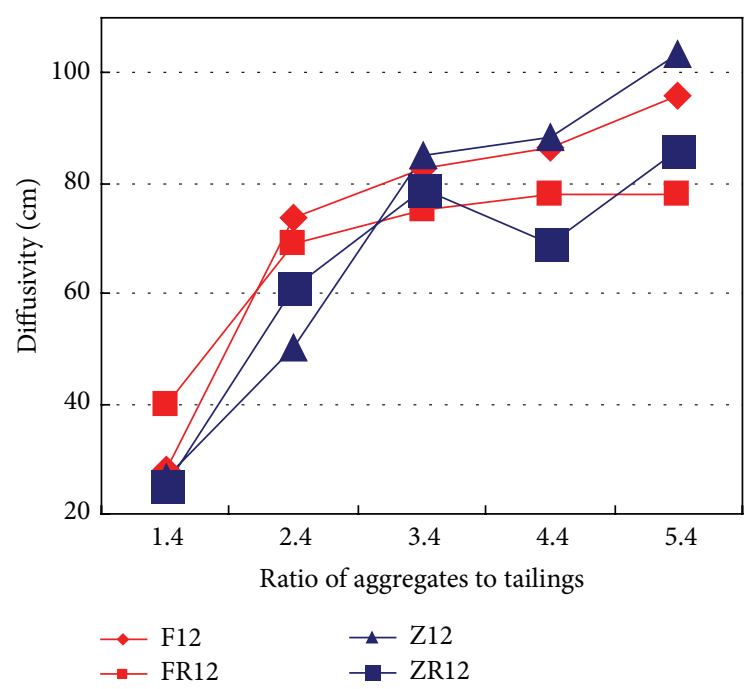

FIgURE 10: Backfill slurry diffusivity using $12 \%$ cement content.

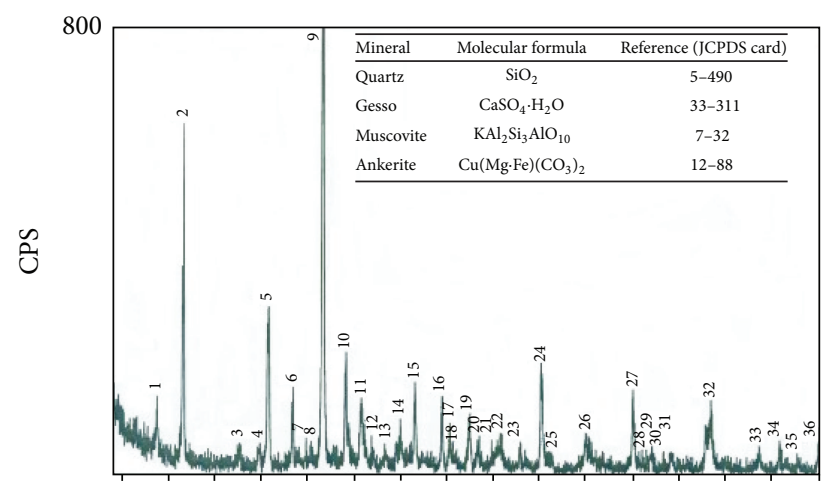

FIGURE 11: X-ray diffraction of neutralization tailings.

$$
\begin{aligned}
& 2\left(2 \mathrm{CaO} \cdot \mathrm{SiO}_{2}\right)+4 \mathrm{H}_{2} \mathrm{O} \\
& \quad \longrightarrow 3 \mathrm{CaO} \cdot 2 \mathrm{SiO}_{2} \cdot 3 \mathrm{H}_{2} \mathrm{O}+\mathrm{Ca}(\mathrm{OH})_{2} \\
& 3 \mathrm{CaO} \cdot \mathrm{Al}_{2} \mathrm{O}_{3}+6 \mathrm{H}_{2} \mathrm{O} \longrightarrow 3 \mathrm{CaO} \cdot \mathrm{Al}_{2} \mathrm{O}_{3} \cdot 6 \mathrm{H}_{2} \mathrm{O} \\
& 4 \mathrm{CaO} \cdot \mathrm{Al}_{2} \mathrm{O}_{3} \cdot \mathrm{Fe}_{2} \mathrm{O}_{3}+7 \mathrm{H}_{2} \mathrm{O} \\
& \quad \longrightarrow 3 \mathrm{CaO} \cdot \mathrm{Al}_{2} \mathrm{O}_{3} \cdot 6 \mathrm{H}_{2} \mathrm{O}+\mathrm{CaO} \cdot \mathrm{Fe}_{2} \mathrm{O}_{3} \cdot \mathrm{H}_{2} \mathrm{O}
\end{aligned}
$$

4.3. Mechanism of Neutralization Tailings Improving the Backfill Strength. (1) As stated in the reaction mechanism, neutralization tailings contain large quantity of $\mathrm{CaSO}_{4} \cdot 2 \mathrm{H}_{2} \mathrm{O}$. During backfill curing, $\mathrm{CaSO}_{4} \cdot 2 \mathrm{H}_{2} \mathrm{O}$ will dissolve from water and crystallize. The crystal grain accretion continues and becomes larger and greater and forms interlaced structure, in which the porosity decreases gradually and the strength increases gradually. This structure combines the aggregates closely and improves the strength of the backfill significantly. Relevant scholars studied the impact of $\mathrm{CaSO}_{4} \cdot 2 \mathrm{H}_{2} \mathrm{O}$ on early stage strength of cement and the result suggests that with appropriate dosage of $\mathrm{CaSO}_{4} \cdot 2 \mathrm{H}_{2} \mathrm{O}$ the early strength of cement increases [11-13].

(2) $\mathrm{CaSO}_{4} \cdot 2 \mathrm{H}_{2} \mathrm{O}$ hydrates with $\mathrm{C}_{3} \mathrm{~A} \mathrm{C}_{4} \mathrm{AF}$ from cement and forms cement bacillus. The following is the reaction mechanism for $\mathrm{C}_{3} \mathrm{~A}$ :

$$
\begin{gathered}
3 \mathrm{CaO} \cdot \mathrm{Al}_{2} \mathrm{O}_{3} \cdot 6 \mathrm{H}_{2} \mathrm{O}+3\left(\mathrm{CaSO}_{4} \cdot 2 \mathrm{H}_{2} \mathrm{O}\right)+19 \mathrm{H}_{2} \mathrm{O} \\
\longrightarrow 3 \mathrm{CaO} \cdot \mathrm{Al}_{2} \mathrm{O}_{3} \cdot 3 \mathrm{CaSO}_{4} \cdot 31 \mathrm{H}_{2} \mathrm{O}
\end{gathered}
$$

The calcium silicate forms a spatial network structure (see Figure 12). Many calcium silicate hydrate ( $\mathrm{CSH}$ ) gelatum ions adhere around it making it a smaller void and hence it has better density. The clavate calcium silicate can be randomly distributed among $\mathrm{C}-\mathrm{S}-\mathrm{H}$, which works similar to micro reinforcing steel bar [13].

(3) Neutralization process produces tailings with crystal grains of $\mathrm{FeAsO}_{4}, \mathrm{Fe}(\mathrm{OH})_{3}$, and $\mathrm{CaSO}_{4}$, which form hydrates in three-dimensional network with $\mathrm{C}-\mathrm{S}-\mathrm{H}$, which is one of the reasons for higher strength from neutralization tailings backfill.

(4) From the granular composition, flotation tailings have an average granular size of $33.5 \mu \mathrm{m}$, with $32 \%$ at $-20 \mu \mathrm{m}$; and the average granular size of neutralization tailings is $24.5 \mu \mathrm{m}$, with $44 \%$ at $-20 \mu \mathrm{m}$. From the granular composition, the average size of neutralized tailings is 0.73 times the average size of flotation tailings and the content of size at $-20 \mu \mathrm{m}$ is 1.37 times that of flotation tailings. Thus, the two kinds of tailings do not have prominent differences on granular composition. Hence, the granular composition of neutralization tailings contributes to a higher backfill strength [14-17].

\section{Conclusion}

(1) Neutralization tailings are a product from Jinfeng BIOX process compared to flotation tailings; neutralization tailings have higher content of $\mathrm{FeAsO}_{4}, \mathrm{CaSO}_{4}$, and $\mathrm{Fe}(\mathrm{OH})_{3}$. Besides, neutralization tailings show smaller average granular size with lesser content of granular composition at $-20 \mu \mathrm{m}$; 


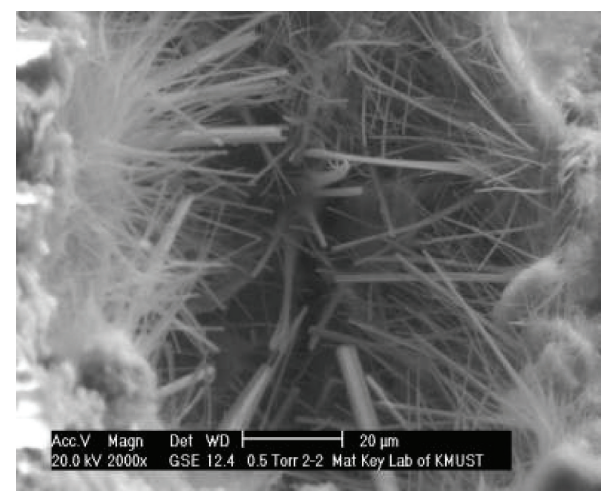

FIGURE 12: SEM picture of calcium silicate.

the two kinds of tailings do not have prominent differences on granules composition. Thus, it is not the granular composition of neutralization tailings that contributes to higher backfill strength.

When the cement content is at 19\%, 7-day, 14-day, and 28day strengths of neutralization tailings are higher than those of flotation tailings by $105 \%-163 \%, 80 \%-102 \%$, and $33 \%-43 \%$, respectively; when the cement dosage is at $12 \%, 7$-day, 14-day, and 28-day strengths of neutralization tailings are higher by $58 \%-77 \%, 50 \%-60 \%$, and $28 \%-51 \%$.

(2) Neutralization tailing is helpful for improving the early stage backfill strength, which is very important for short curing time of backfill in drives and improves the production from stope.

(3) When neutralization tailing is used for backfill, the UCS value is nearly in inverse relation with aggregates-totailings ratio. The strength of backfill reaches its maximum when the ratio of aggregates to tailings is 2.4.

(4) The flow behavior of backfill with neutralization tailings is less active. As the value of slump and diffusivity of two kinds of tailings is not more than $6 \%$, it does not have any impact on liquidity.

(5) $\mathrm{CaSO}_{4} \cdot 2 \mathrm{H}_{2} \mathrm{O}$ is produced in abundance during tailings neutralization. As the crystal grain accretion continues, the grain size becomes larger and larger and forms interlaced structure, in which the porosity decreases gradually and the strength increases constantly. This structure combines the aggregates closely; and $\mathrm{CaSO}_{4} \cdot 2 \mathrm{H}_{2} \mathrm{O}$ reacts with cement and forms a clavate cement bacillus, which creates a spatial network structure and works similar to micro reinforcing steel bar, thus increasing the early stage strength of cement.

(6) Compared to flotation tailings, the use of neutralization tailings for backfill does not impact the fluidity of backfill but helps in improving the strength. Hence, it is favorable to use neutralized tailings to replace currently used flotation tailings for underground stope backfilling.

\section{Competing Interests}

The authors declare that they have no competing interests.

\section{Acknowledgments}

This work was financially supported by the China National Science and Technology Support Program during the 12th Five-Year Plan Period (2012BAB08B02) and the National Natural Science Foundation of China (51374034, 51304011, and 51374035).

\section{References}

[1] F. Gao, K.-P. Zhou, W.-J. Dong, and J.-H. Su, "Similar material simulation of time series system for induced caving of roof in continuous mining under backfill," Journal of Central South University of Technology, vol. 15, no. 3, pp. 356-360, 2008.

[2] B. Han, Backfill Reliability Analysis and Ground Control Optimization of No.1 Ore Body in Jinchuan No.2 Mine, Central South University, Changsha, China, 2004.

[3] R. M. Rankine and N. Sivakugan, "Geotechnical properties of cemented paste backfill from Cannington Mine, Australia," Geotechnical and Geological Engineering, vol. 25, no. 4, pp. 383393, 2007.

[4] C.-Q. Zhao and N.-L. Hu, "Influence of cemented filling on stope stability," Journal of Liaoning Technical University, no. 1, pp. 13-16, 2008.

[5] T. Belem and M. Benzaazoua, "Design and application of underground mine paste backfill technology," Geotechnical and Geological Engineering, vol. 26, no. 2, pp. 147-174, 2008.

[6] X.-M. Wang, J.-X. Li, and P.-Z. Fan, "Applied technique of the cemented fill with fly ash and fine-sands," Journal of Central South University of Technology, vol. 8, no. 3, pp. 189-192, 2001.

[7] Q.-L. Zhang, G.-Y. Hu, and X.-M. Wang, "Hydraulic calculation of gravity transportation pipeline system for backfill slurry," Journal of Central South University of Technology, vol. 15, no. 5, pp. 645-649, 2008.

[8] A. P. Tapsiev, A. N. Anushenkov, V. A. Uskov, Y. V. Artemenko, and B. Z. Pliev, "Development of the long-distance pipeline transport for backfill mixes in terms of oktyabrsky mine," Journal of Mining Science, vol. 45, no. 3, pp. 270-278, 2009.

[9] X.-M. Wang, B. Zhao, Q.-L. Zhang, and D.-S. Xu, "Cemented backfilling technology with unclassified tailings based on vertical sand silo," Journal of Central South University of Technology, vol. 15, no. 6, pp. 801-807, 2008.

[10] A.-X. Wu, B. Han, and T.-Y. Liu, "Backfill technical-economic analysis of underhand drift cut-and-fill stoping based on reliability theory," in Proceedings of the 8th International Symposium on Mining with Backfill (Minefill '04), pp. 41-44, The Nonferrous Metals Society of China, Beijing, China, 2004.

[11] S.-J. Cai, Mechanics Foundation of Mine Backfill, Metallurgical Industry Publishing House, Beijing, China, 2009.

[12] J.-S. Chen, B. Zhao, X.-M. Wang, Q.-L. Zhang, and L. Wang, "Cemented backfilling performance of yellow phosphorus slag," International Journal of Minerals, Metallurgy and Materials, vol. 17, no. 1, pp. 121-126, 2010.

[13] W. Sun, "Experimental research on properties of fly ash-based grouting material," Kunming: Kunming University of Science and Technology, vol. 19-21, pp. 22-57, 2009.

[14] D.-Q. Deng, Y.-T. Gao, and S.-C. Wu, "Destroy energy dissipation characteristics of cement tailings backfill under splitting tensile condition," Journal of University of Science and Technology Beijing, no. 2, pp. 144-148, 2009. 
[15] M. Fall, T. Belem, S. Samb, and M. Benzaazoua, "Experimental characterization of the stress-strain behaviour of cemented paste backfill in compression," Journal of Materials Science, vol. 42, no. 11, pp. 3914-3922, 2007.

[16] M. C. Nataraja and Y. Nalanda, "Stress-strain behaviour of flowable fill," Geotechnical and Geological Engineering, vol. 27, no. 3, pp. 341-354, 2009.

[17] B. Han, S.-X. Zhang, J. Deng, and X.-L. Wang, "Determining method of backfill strength for underhand drift cut-and-fill stopping based on reliability theory," Journal of China University of Mining and Technology, vol. 35, no. 3, pp. 372-376, 2006. 

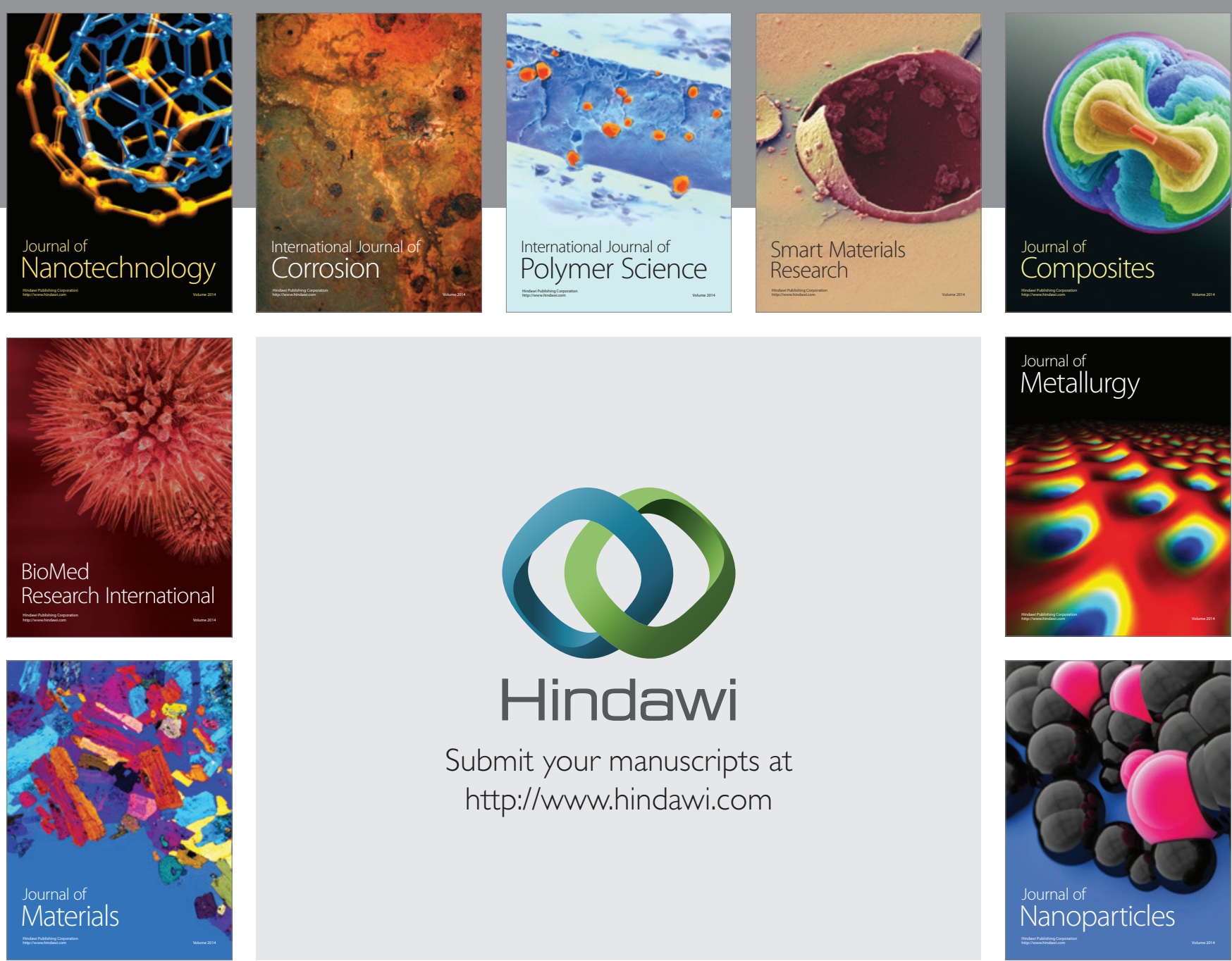

\section{Hindawi}

Submit your manuscripts at

http://www.hindawi.com

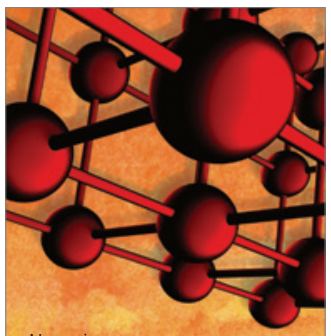

Materials Science and Engineering
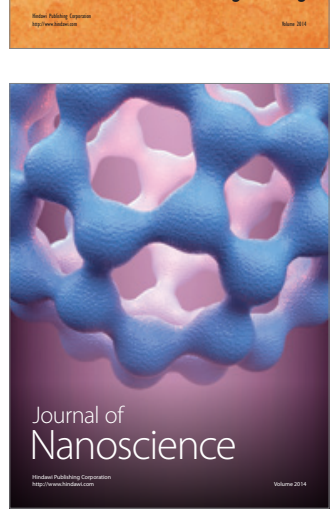
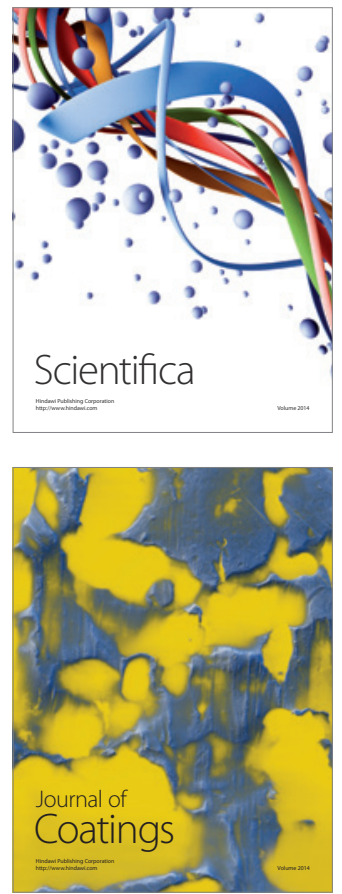
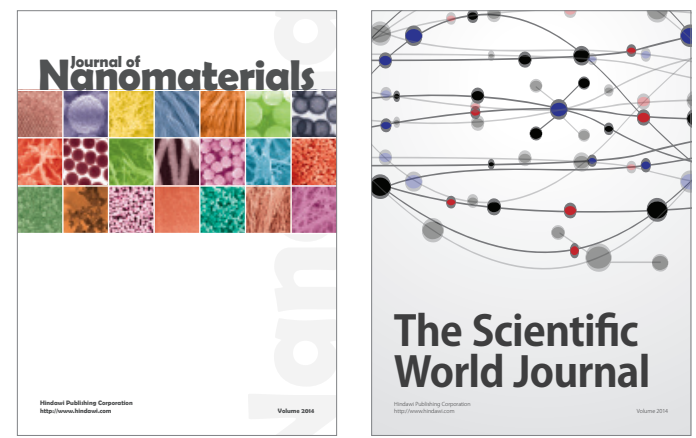

The Scientific World Journal
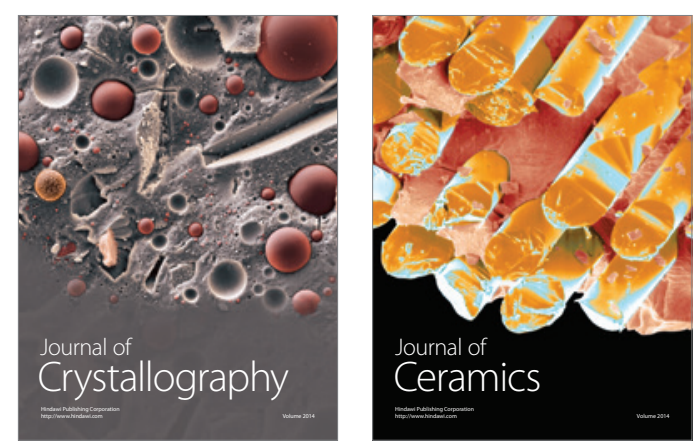
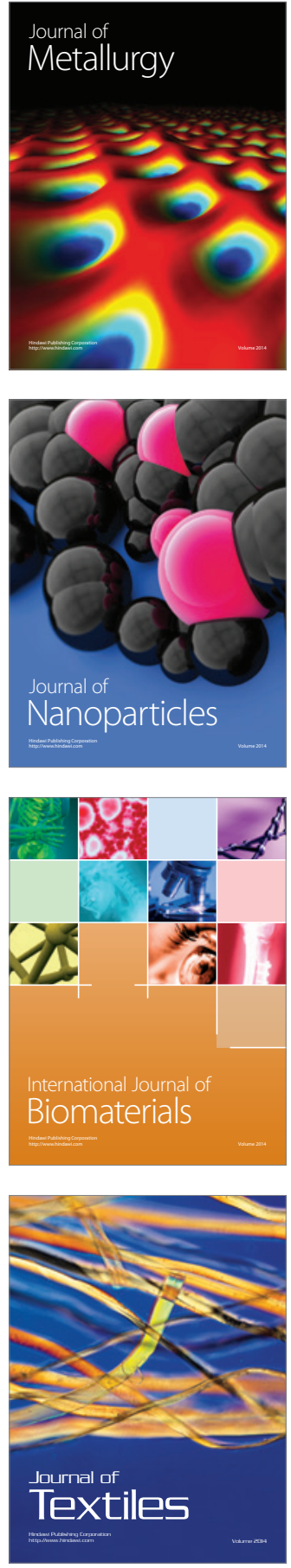